Measuring the Effects of Public Support Schemes on Firms' Innovation Activities

Rahel Falk 


\section{Measuring the Effects of Public Support Schemes on Firms' Innovation Activities}

Survey Evidence from Austria

Rahel Falk

WIFO Working Papers, No. 267

January 2006 


\title{
Measuring the effects of public support schemes on fims' innovation activities \\ Survey evidence from Austria
}

\author{
RAHELFALK \\ Austrian Institute of Ec onomic Research (WIFO) \\ A-1103 Vienna; P.O. Box 91 \\ Phone: 43-1-7982601-238; Fax: 43-1-7989386 \\ Rahel.Falk@wifo.ac.at
}

\begin{abstract}
:
This paper disc usses conceptual frameworks for measuring the effects of innovation policy and begins with applying conventional descriptive methods to explore how firms rate and rank the merits of public intervention. Based on survey data from some 1200 Austrian fims we then challenge the hypothetical survey question ("What would you have done if public support was denied?") by comparing the respective answers with changes that actually occurred when public assistance was refused. This is a contribution to the ongoing literature as is the attempt to relate any of the observed additionalities to the firms' characteristics, their perceived bariers to innovation and the degree they make use of the public support system. The effects of polic y interventions prove to be cumula tive in a dual sense. On the one hand, our results confim the well-known notion that large firms make the best use of funds. On the other hand, substantial changes in the way a company undertakes R\&D\&l-related activities appear to only result from multiple policy interventions of different kinds. While supported firms tend to immediately increase their resources devoted to innovation projects, the result-based concepts of additionality only come into effect once a threshold level of intervention has been reached. Acknowledging that a public innovation support system already inc entivises potential beneficiaries to change their innovation-related behaviour, and that eventual success in terms of outcomes does not arise from some discrete support measure, but from the synergies of multiple policy action, we conclude that future work should focus more on the evaluation of portfolios of programmes and their interactions.
\end{abstract}

JEL: C 25, C42, H50, O31

Keywords: innovation polic y; policy evaluation; methods

I would like to thank Luke Georghiou, Michael Paffermayr and two anonymous referees for helpful comments. 


\section{Introduction}

Depending on the perspective of innovation, or rather on the perspective of innovation failures, policy makers hold different views on the main role of adequate policies. The traditional school identifies three prime sources of market failure which impede the generation of optimal amounts of knowledge in the fields of science, technology and innovation (ST). ${ }^{1}$ First, innovating firms bear high costs when generating new knowledge, but cannot reap the full benefits thereof, because the knowledge spills over to society as a whole, competing fims included. This is the well-known appropriability problem associated with the nature of knowledge as a public good; it causes distinct disinc entives for ST-related investments. Second, the primary generation of knowledge may require a scale of effort larger than individual firms a lone could generate or susta in. Third, initial investments involve a range of risks and uncertainties, yet at the same time markets that insure against these risks either do not exist or they do not function properly due to information asymmetries on the part of the innovating fim and potential investors. ${ }^{2}$ If the primary generation of new knowledge is constrained, then the govemment should assist fims by channelling sufficient amounts of resources to the innovation activity. In this light, policy intervention is considered the more effective the more fims are encouraged to spend their resources on STl-related activities. As the traditional perspective on innovation processes is a linear one, the success of public assistance should be equally visible in tems of greater innovation outcomes.

The system failure perspective locates the bottlenecks of innovation not so much in the primary generation of knowledge, but in a more fundamental problem. ${ }^{3}$ In the first place, firms a re said to suffer from "bounded vision" (Fransman, 1990, Georghiou et al. 2003, p. 28). When faced with high-pressure deadlines managers tend to disregard the value of new knowledge, unless it emerges from areas where the fim is currently carying out activities. If they are aware of the importance of new knowledge, the firm's ability to transfer, assimilate and ultimately apply knowledge to commercial ends often requires a (much too) high level of absorptive capacity. Modem approaches to innovation policy therefore focus on the acquisition of leaming capabilities and problem-solving skills, including the ability to know where complementary expertise can be found. Consequently, innovation policies are considered the more effective the more they contribute to the intermediate goals of knowledge acquisition and diffusion. This approach accords well with the concept of behavioural additionality as originally introduced by Buisseret et al. (1995). It broadens the traditional additionality concepts by investigating whether policy intervention has led the actors to become more involved in ST-activities. It also assesses whether there have been permanent changes in the conduct of a company, especially in the institutiona lization of any

\footnotetext{
1) An overview on the tra ditional neoclassical rationales for STl-policy is given, for instance, in Stoneman and Vickers (1988) and Sundbo (1998).

2) Both the public good argument as well as the risk argument have first been brought forward by Arrow (1962) in connection with knowledge. Indivisibilities or scale factors in ST have been first argued by Nelson (1959). Subsequently these arguments would come as the prime justific ation for a neoclassically inspired innovation policy.

3) Literature surveys include Dodgson and Rothwell (1994), Freeman (1994), Metcalfe (1995), Sundbo (1998) and Fagerberg et al. (2004), section II.
} 
-3 -

activities related to the innovation process (Aslesen et al., 2001). In short, the foc us is on the building of innovation capabilities and competence building in general, as well as on the companies' ability to make use of new technologies and R\&D-procedures elsewhere. If this is the case, this can strengthen the company's ability to absorb new knowledge. It should be noted that this form of competence building may also benefit other participants in the innovation system, including customers and collaboration partners, thus contributing to a permanent and susta inable increase in a country's innovation investment.

This paper discusses conceptual frameworks for measuring the effects of innovation polic $y$, applies desc niptive methods to explore how fims rate and rank the ments of intervention and suggests some methodical extensions. The paper is organised as follows: Section 2 describes and classifies various a dditiona lity concepts and their sub-dimensions and discusses how they interrelate with each other. While there are numerous econometric studies on both input and output additionality ${ }^{4}$, empiric al evidence on behavioural additiona lity has remained sparse and ma inly a nec dotic until recently. This defic iency is ma inly due to the limited availability of useful data. Physical resource inputs are easy to track and innovation outcomes are recordable, however intangible behavioural changes resulting from govemment intervention are much more diffic ult to monitor. Accordingly, the third section briefly discusses empinical approaches to the behavioural concept, while the fourth section applies and extends the present methods. Based on survey data from some 1200 Austrian fims we qualify the descriptive findings on the effectiveness of innovation polic y by relating any of the observed additiona lities to the firms' characteristic s and their perceived ba miers to innovation. This is a contribution to the ongoing literature, as is the attempt to explore the robustness of respective results from survey data. We challenge the survey question "What would you have done if public support was denied?" by companing the respective answers with changes that actually occurred when public assistance was refused. The findings from the fourth section offer some insight into the appropriateness of current innovation support mea sures in Austria, and challenge the traditional concepts of how to measure their effects. The last section concludes with a disc ussion of the direction which future work on a dditionality should take.

\section{Conceptualising Additionality}

Several additionality concepts have been proposed as a way to measure the effects of public assistance on fims' innovation activities. They can be classified in three broad categories: resource-based concepts, result-based concepts and concepts that measure the success of policy intervention by examining desirable changes in the process of innovation.

\footnotetext{
4 David et al. (2000) survey the econometric contributions to input additionality, Streicher et al. (2004) provide evidence for Austria and García-Quevedo (2004) conducted a meta-analysis on this issue. A comprehensive survey of the microeconometric evidence on output additionality is due to Klette at al. (2000). More recent intemational contributions on output additionality include Branstetter and Sakakibara (2002) or Czamitzki et al. (2004). Austrian evidence is provided by Garica and Mohnen (2004) and Falk (2004).
} 
The most obvious way to evaluate the effectiveness of public support is to determine whether it has resulted in so-called project additionalities (e.g. Davenport et al., 1998). Project additionalities a re in place if the research project is cancelled, unless it is supported by public funds. It has been observed, however, that in many cases fims do not follow a rigorous approach when deciding on implementation or non-implementation. Instead, they tend to adapt the size of their projects or investments when public support is denied or granted. Accordingly, so-called scale additionalities a re said to be on hand if public funding allows the project to be conducted on a larger scale. In a way, scale additionalities describe the gradual variant of binary defined project additionalities. The third concept which relates public intervention to its impact on the fim's resources is input additionality. Here, the focus is on whether and to what extent fims increase their private spending on innovation-related activities when supported - i.e. whether the firm itself spends at least one additional Euro on the research project for every Euro received in subsidy. This concept emphasises the leverage effect of public funding and is therefore the most refined one of the resource-based concepts. Clearly the three aforementioned concepts may stand in conflict with each other. One can easily imagine a situation in which project and scale additiona lities occur, but the fim does not spend the entire subsidy on its target activity, let a lone contribute its own funds (hence no input additiona lity).

The main problem with resource-based notions of additionality is that they rely on the oversimplified linear model of innovation which assumes a direct link between primary "innovation inputs" and respective payoffs. However, additional innovation resources do not inevitably result in increased innovation output and conversely, innovations are not merely the result of increased investment in tangible assets. Empiric al evidence suggests that many companies, especially in the service sector, typically do not innovate by expanding R\&Drelated inputs (Gottschalk and Janz, 2003, and Tether, 2003). Instead, their innovation activities tend to rely more on creative and cooperative efforts, organisational change and new ways of offering services. E-banking and e-commerce are good examples of the latter.

Output additionality therefore dea ls directly with the most decisive impact, i.e. with the effect of public funding on results. It measures the proportion of output that would not have been achieved without public support. Output is either defined in terms of marketable output (e.g. patents or succ essful innovations) or commercial output (e.g. sales or profits that a re directly attributable to public R\&D assistance). Results might also be defined in terms of enhanced productivity or a better competitive position, in which case the tem impact additionality has been suggested. For obvious reasons, the case of impact additionality is hard to verify and the same applies to output additiona lity when the relevant indicator is commercial output. The innovation process requires a certa in amount of time, as does the final product launch. With such a long time to market, the effect of initial public assistance is likely to be blured. Many empincal studies therefore draw on marketable output, especially patents. However, this only superfic ially solves the measurement problem: Patents or other intellectual research output are of no value to the firm unless they a re converted into cash.

Hence, the fundamental drawback of the result-based measures is that the relevant dimension of innovation outcome cannot easily be attributed to intervention, while 
resourced-based measures leave the crucial transformation process of innovation input to innovation output within the black box. As a way out of this dilemma, Rigby (2003) proposes to condition the provision of public money on high output additionality, while high input additionality should be treated as a kind of second order condition. In light of the scarcity of public funds, he (among others) argues that the second order test ensures that publicly funded $R \& D$ does not substitute or even crowd out private R\&D-investment and that the latter additiona lity concept serves as "a measure of the leverage effect of public money on the private resources of the firm".

Without questioning the ultimate need for an efficient use of public resources, there is increasing awareness of the fact that the traditional additionality concepts do not adequately capture the impact of public intervention on the innovation process itself. Accordingly, a third notion of additionality has been introduc ed: Behavioural additionality. It deals with "the difference in fim behaviour resulting from the intervention" (Georghiou, 1997). These changes should be permanent in character and should allow for a more efficient transfomation of innovation inputs into innovation outputs, i.e. it is assumed that fim behaviour is changed for the better. The largely conceptual papers on Behavioural Additionality have proposed several refinements. ${ }^{5}$

Scope additionalities refer to cases where the coverage of an activity is expanded to a wider range of markets, applications or players than would have been possible without public assistance. The case of assisted fims advancing into new research areas could be reflected in a greater risk profile of the innovation projects, since activities in areas beyond the firm's key competencies entail grea ter technical diffic ulty (hence an increase in technical risk) and bring about less predic table business success (hence an increase in commercial risk). On the other hand, new partnerships between the business and academic spheres could serve as prime examples for an enlargement of the original group of participants. In the same way collaboration networks (within or between sectors) which would not otherwise occur are an indicator of scope additionalities. As collaboration and networking involve both individual and organisational leaming, thereby increase the competencies of the actors and enhance their absorptive capacity, some authors (such as Hyvärinen, 2005) refer to the positive impact on competencies and expertise as cognitive capacity additionality. Whether cooperations in innovation a re classified as sc ope additiona lities or cognitive c apa city a dd itiona lities, or even as the desirable result of some support measure - the crucial point is that the firm's future innovation behaviour is affected in a positive and sustainable way.

At last, funding can affect the timing of the project. Acceleration additionalities are said to be in place if participation in innovation schemes speeds up the course of the project. Observable outcomes are, for example, an earlier starting date of the project, a shorter implementation phase, or project results accessible at an earlier date. Firms could also anticipate acceleration additionalities (shorter time to market) and therefore be less reluctant to engage in more long-term projects. If at the same time these long-term projects

\footnotetext{
5 See Georghiou (1997 and 2002), Georghiou et al. (2000 and 2003), Lukkonen (2000), Papaconstantiou and Polt (1997).
} 
-6 -

are geared to strategic objectives and supported fims decide to camy on research in a reas beyond short-tem business needs, then acceleration additionalities come along with scope additionalities. Of course, the "initiation of new lines of research" event could also be classified as an impact additionality if the fim thereby succeeds in strengthening its competitive position.

Figure 1: Additionalities in resources, processes and results

Reso urce-based concepts

Result-based concepts

\begin{tabular}{|c|c|c|c|c|}
\hline $\begin{array}{l}\text { Project } A . \\
\text { Input } A .\end{array}$ & Scale A. & Acceleration A. & $\begin{array}{c}\text { Scope A. } \\
\text { Cognitive Capacity A }\end{array}$ & $\begin{array}{l}\text { Output } A \text {. } \\
\text { Impact } A \text {. }\end{array}$ \\
\hline
\end{tabular}

Process-based concepts (behavioural change)

A final note refers to the conceptual fuzziness with respect to scale additionalities. When a fim engages in larger innovation projects as a result of funding, it has changed its behaviour to such an effect that larger amounts of resourc es a re channelled into the activity. I prefer to rank scale additionalities among the resource-based concepts, but other authors classify them as a sub-category of behavioural additionality. Figure 1 illustrates how the subcategories of behavioural additionality (scale, acceleration, scope and cognitive capacity) merge at the interfaces to the resource-based and the result-based additionality concepts.

\section{Empinical approaches to Behavioural Additionality}

Many papers dealing with behavioural additionality allude to the econometric approaches, but do not apply them. To the best of my knowledge, the rare exception is a paper by Wong and $\mathrm{He}$ (2003) who exploit survey-data from 135 manufacturing firms in Singapore. In fact it is hard - if not impossible - to adapt standard econometric techniques to the behavioural concept. Variables that capture behaviour would have to be regressed on the incidence or even the size of public assistance, while one controls for other influencing factors. The cardinal problem is, of course, finding suitable left-hand side variables. Behaviour is as such inherently intangible; it only becomes manifest in terms of results. We could, for instance draw conclusions about the firm's attitude towards risk based on the observed volatility of profits, or we could estimate the time-frame of its research activities by looking at the average duration of the projects. However, even if a fim reacts promptly in some well-defined measure, the resulting observable changes in behaviour will lag behind. Clearly, the greater the time lag, the less compelling is the assumed link between cause and effect. Although this concem genera lly applies to a ny of the above a dd itiona lity concepts, it is particular severe in the fuzzy behavioural context. This is also true for the other main problem connected with the regression approach: the fact that the control variables, and arguably an entire range of additional, unobserved factors, not only affect the realised additionalities, but also the 
decisions of the managers of some well-defined programme to support some firm. Advanced papers address such correlations and instrument the participation decision. ${ }^{6}$ The major diffic ulty is no less challenging than the former one, namely to find valid instruments that have an influence on the support variable, but not on the behavioural changes resulting from the intervention.

These problems are hard to solve. For this reason, hitherto existing empirical a nalyses of behavioural additiona lity a re based on one of two frameworks. In the first, supported firms a re compared to unsupported ones in tems of any of the aforementioned indicators of behaviour, e.g. with respect to the size of their projects, their willingness to cooperate, and their willingness to engage in risky $R \& D$, etc. Simple comparison group a nalyses have been camied out, for instance, by Hyvärinen (2005) for Finnish fims (TEKES-customers and noncustomers) or by Shipp et al. (2005) for US fims (ATP-customers and non-customers). The general picture emerging from these studies is that supported fims are characterised by significantly superior innovation performance and related issues than the non-supported ones. The serious drawback of the comparison group approach is that - again - one cannot tell whether (behavioural) additionalities are merely attributable to the type of firms that select into support schemes. To separate the selection effect from the funding effect, matching methods would be in order. This boils down to a conventional comparison group analysis with the crucial difference that the descriptive analysis draws on a "matched" sample. Ideally, matched fims are identical except for their funding status. Yet such an approach has never been followed in the behavioural context.

The other way to assess the issue of behavioural additionality - as followed, for instance, by Davenport et al. (1998), Aslesen et al. (2001) or Pegler (2005) - is to question assisted fims directly. This would involve asking recipients of public support how their innovation related behaviour changed, asking formerly supported fims how the withdrawal of assistance affected their innovation related behaviour, and asking non-supported firms how their innovation related behaviour would have changed had they received support. Surveys are a good solution, provided, of course, the respondent does not answer strategically and provided she is able to reflect behavioural changes in a counter-factual situation.

\section{The effects of innovation policy: survey evidence from Austria}

Based on recent survey data, the following chapter provides some evidence on the effectiveness of the Austrian innovation support system. After introducing the data and the survey design, section 4.2 looks at the additionality effects as claimed by the respondents. One of the helpful features of our survey is that it includes questions on behavioural change in the event of rejection which are not merely hypothetic al (i.e. "Would the project have been conducted without public support?"). Instead, we can also compare such results with answers from respondents whose proposals have actually been rejected. The results from this comparison will be presented in section 4.3. At last section 4.4 qualifies the previous findings

${ }^{6}$ In Wong and He (2003) the funding status remains exogenous. 
- 8 -

by identifying the types of fims which make best use of public assistance and by estimating the level of intervention necessary to trigger any of the afore mentioned dimensions of ad ditiona lity.

\subsection{The data and design of the survey}

In 2004 the major federal R\&D support scheme in Austria (then known as the FFF, now part of the FFG) commissioned a study to see how customers evaluate its performance. ${ }^{7}$ In this context, a detailed questionnaire was sent to 3652 fims that had submitted a research proposal to the FFF - whether it proved successful or not. A total of 36 percent of these fims (1298) filled out and retumed the questionnaire on time, thus comprising our revised sample.

The survey began with a basic background section on va rious fim characteristics, such as the number of employees, sectoral affiliation or year of foundation of the firm. We distinguished between four aggregate branches: low-tech as opposed to R\&D-intensive manufacturing industries (24 percent and 30 percent of the revised sample) and traditional as opposed to knowledge-intensive services (11 percent and 28 percent of the revised sample). A total of 72 fims fell into the primary sector and were deleted from the following empincal analysis, as were those companies which failed to report their sectoral affiliation. The first two columns of Table 5 in the Appendix provide some details on the aggregation of branches. Second, we identified four size groups. Every third sample fim belonged to the mic ro-sector which consists of fims with less than 10 employees. Another third of the fims employed between 10 and 99 persons and 12 percent employed between 100 and 249 employees. 14 percent of the fims were considered large, having more than 250 employees. Table 6 in the Appendix gives the joint distribution of sectoral affilia tion and firm size categories.

Among other issues, subsequent sections deal with perceived bamiers to innovation ${ }^{8}$ and the type(s) of public support granted during the previous eight years (if any). It tumed out that only 11 percent of the sample fims had not been assisted by any innovation support measure, i.e. they had received no tax relief and no direct assistance from national or European support sc hemes.

\subsection{Desc niptive evidence on resource-based and behavioural additionalities}

Regardless of their funding status, fims were first asked to assess the benefits accrued from the entire range of (potentially) a vailable innovation support measures. The exact wording of the question was: "How does the Austrian system of innovation support affect the ways your company camies out innovation-related activities?" The respondents were then asked to choose from three possible altematives, e.g. "we camy out bigger projects", "the scale of the projects remains unchanged" and "we camy out smaller projects". Figure 2 illustrates the answers.

\footnotetext{
7 For details on the survey see Schibany et al. (2004), chapter 6.

8 The hampering factors will be discussed in section 4.3. Figure 3 in the Appendix provides a list that ranks the urgency of the proposed factors.
} 
The first sumprising result was that even unsupported fims reported that they had realised various types of additiona lities - a finding that casts serious doubt on the genera lly assumed direction of causality. Obviously, anticipated changes in firm behaviour not only result from participation, but also from the funding criteria. If the fim meets these criteria, and maintains them irrespective of its acceptance by the funding institution, then the additionality arises from the application and is not the result of participation in support measures. As fims generally change their manner of undertaking $R \& D$ activities in a gradual way, the question of cause and effect appears to be anything but settled within the behavioural context.

Figure 2: Additionalities arising from the Austrian innovation support systema)

\begin{tabular}{|c|c|c|c|}
\hline R\&D-a c tivity & more & unchanged & less \\
\hline Project size & bigger & unchanged & smaller \\
\hline Time-frame & more long-run & unchanged & shorter \\
\hline
\end{tabular}

\begin{tabular}{|l|l|l|}
\cline { 2 - 3 } Own R\&D-expenditure & unchanged & less \\
\cline { 2 - 4 }
\end{tabular}

\begin{tabular}{c|c|l|}
\cline { 2 - 3 } Cooperation & unchanged & less \\
\cline { 2 - 3 }
\end{tabular}

\begin{tabular}{|c|c|c|}
\hline misk & unchanged & less \\
\hline
\end{tabular}

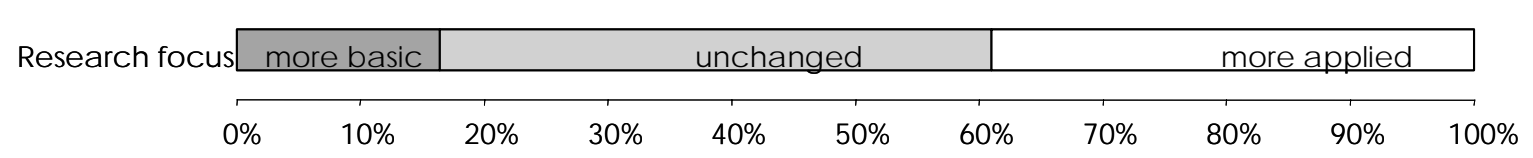

Source: FFF-survey; a) includes supported and unsupported fims

Every other firm intensified its research activities giving rise to project additionalities. 16 percent of the firms invested more in basic research, while 40 percent enlarged their applied work. In contrast to the other (sub-) dimensions of additionality, there is no a priori reason why either of these changes in research focus should be regarded as preferable. This said, the vast majority of fims reacted in the anticipated "right way", so there can be no doubt as to the general effectiveness of the Austrian support system for innovation related activities. In addition to the overall project additionality, additiona lities accrue in terms of the size of the project with 48 percent of the firms realising scale additiona lities. As regards the time-frame of the project, 45 percent of the sample fims stated that they had engaged in more long-term projects indic a ting that assisted fims take acceleration additiona lities into a ccount. Classic al input additiona lity ranked fourth, followed by greater willingness to undertake risky R\&D and greater openness to collaboration (both at 33 percent).

How do these findings compare to other studies? During the last two years an OECD working group has been exploring the measurement of behavioural additionality through a series of linked national studies (OECD 2005). The studies are framed in very specific national contexts 
and the approaches varied considerably in terms of target group and survey design. The contributions widely agreed on the importance of the behavioural aspect in evaluating the effects of polic y. Apart from this general finding it is hard and arguably not rather useful to present overall result tables. There is certainly wide agreement that acceleration additiona lities matter a lot - which is perfectly in line with our findings. On the other hand, the role of public support in influencing firms' cooperation strategies is more controversial. The study from Finland answered in the negative, while evidence from Germany and the US concluded that cooperation strategies were influenced in a highly signific ant way. The way respondents see this issue obviously hinges on the exact wording of the survey question. The assisted project might have involved cooperation, existing partnerships might have been intensified or additional cooperations might have been newly founded. As an example, in our case some 30 percent of the respondents claim that public support helps them to engage more in cooperative activities. At the same time every other fim states that the assisted project involved cooperation of some kind. Some of the confusion might also be attributable to different classifications of observed additionalities. If the aim of a specific support programme precisely is to establish partnerships, then eventual success comes rather as a project additiona lity, i.e. the (collaboration) project would have failed without intervention.

\subsection{Behavioural changes in case of rejection: hypothetic al vs. actual situations}

The a nalysis of directly asked questions on additionality assumes that the respondents are indeed able to reflect on their behaviour in hypothetical, counter-factual situations and that they are telling the truth to the best of their knowledge. However, as respondents have an interest in the continuation of public support, they might be tempted to over-emphasize the merits thereof (Saka kibara, 1997). On the other hand, one could argue that companies might be reluctant to admit their dependency on public funds in order to demonstrate that they are in line with the basic funding principles of complementarity and susta inability. Either way, the differences between hypothetic al and real situations should, if possible, be assessed, and our survey allows for this kind of investigation.

Table 1 presents some evidence on hypothetical and actual project additionalities. It is important to note that analyses in this sub-section do not refer to the Austrian innovation support system "in general", but to the perceived merits of one particular scheme - that of the FFF. Hypothetical a nswers come from fims having never experienced rejection by the FFF, while the last column gives the percentage answers of fims whose applications have failed at least once. Based on their experience, these respondents can report on what actually happened to a rejected project. Table 8 in the Appendix details the analysis by firm size and sectoral affiliation.

Obviously, the readiness to camy out the original project even when no support was granted has been systematic ally underestimated. Conversely, a substantially smaller fraction of fims (47 as opposed to 57 percent) would be prepared to implement a revised version of the proposed project. This suggests that the revision of research proposals requires more of an effort than fims generally anticipate. In consequence, more fims than expected either cancel the project or implement it without changes. The extent of a firm's fa lse assessment of 
- 11 -

Table 1: Implementation/non-implementation if application is rejected

In case of rejection, the project...

... is carred out without changes (no project additionality)

... is ca ried out, but with changes (partial project additionality)

... is cancelled (full project additionality)

Number of sample fims

Hypothetical Scenarioa) Actual Consequenceso)

13.36

56.82

29.82

21.93

29.82

So urce: FFF-survey; a) only refers to fims that have never expenienced rejection by the FFF; b) answers relate to fims that have experienced rejection by the FFF.

its own readiness to camy out a revised version of the project is particularly high for companies with more than 10 but fewer than 100 employees, while micro-sector firms generally display the most realistic self-assessments. ${ }^{9}$ The detailed analysis by fim-size also shows that the largest firms are not those which prove to be the least reliant on FFF-funding. It is true that within this size category the share of respondents who claim that no project additionalities arise from FFF-funding is highest and, conversely, the share of companies reporting full project additiona lity is lowest. However, when we depart from the hypothetical scenario and take a look at the actual consequences, we find that additionalities are the lowest for companies with above 100 and below 250 employees. This irregularity aside, it remains true that small fims are the most vulnerable to a withdrawal of support, corroborating the findings from the recent studies on behavioural additionality (OECD 2005). In summary, the detailed analysis by fim size in Table 8 supports a U-shaped relationship between the size of the fims and the effects of public funding.

Furthermore, the right panel of Table 8 in the Appendix shows that the decision to implement a project even when FFF-assistance is denied depends on the firm's sectoral affiliation. Service sec tor fims seem to be the most sensitive to FFF intervention, with a share of about 40 percent stating that the project had to be cancelled when FFF-funding was denied.

Table 2 sheds some light on the revisions that would have come into effect had the FFF decided not to assist the project. Accordingly, the sample is reduced to the set of fims claiming that the project would have been implemented in some revised form in case of rejection. We observe great unanimity with respect to the accessibility of project results. In other words, the conceived and actual consequences do not really differ from each other.

Table 2: Behavioural Additionality: adaptations if application is rejected

\begin{tabular}{l|cc} 
& Hypothetical Scenario & Actual Consequences \\
\hline Smaller size of the project (total) & 78.11 & 62.38 \\
Postponed starting date of the project (total) & 35.53 & 46.43 \\
Longer duration of the project (total) & 56.73 & 63.64 \\
Later accessibility of project results (total) & 64.59 & 66.01 \\
Technical demands less sophisticated (total) & 51.50 & 42.08 \\
\hline Number of sample fims & 414 & 213
\end{tabular}

Source: FFF-survey

\footnotetext{
${ }^{9}$ See Table 8 in the Appendix (left panel: analysis by firm size).
} 
Two out of three respondents agree that project results could only be exploited at some point in time later than the original target date, supporting the notion that so-called "acceleration additionalities" really matter. We find that acceleration additionalities originate as an immediate consequence of postponed starting dates and prolonged implementation phases when there is no public sponsoring. In fact, delays are generally much more severe than expected. Finally, Table 2 shows that the fewest concessions are made when it comes to technical demands. In fact, the actual consequences are less severe than the hypothetical ones and the same is true for the scale issue. Still, more than 60 percent of the rejected fims say they ca mied out the project on a sma ller sc ale when FFF-a ssistance was denied.

\subsection{Qualifying the results: what promotes additionalities from public funding?}

It is only a first step to verify what kinds of additiona lities have been triggered to what extent. In order to draw some policy conclusions on the advancement of the national innovation support system, it is important to know what types of fims are partic ularly sensitive to policy interventions. Do observed changes in fim behaviour depend on certa in fim characteristic s? Is it merely the "usual candidates" who are in a position to reap the benefits of public assistance, or is the "marginal claimant" equally successful? In particular, is the support system responsive to perceived ba miers to innovation? And how much support is necessa ry to trigger (behavioural) changes in favour of susta ina ble STl-investment?

To assess these issues in a methodologically sound way, it is necessary to go beyond the descriptive approach. In the following, we use the categorical variables from Figure 2 as dependent variables and estimate a series of ordered probit regressions. Note that the probit model does not "prove" the case of (behavioural) additionality by means of econometric techniques - based on the survey data at hand the former descriptive analyses give clear answers. Instead, the results will deepen the understanding about the drivers of additionality and the response pattems of fims to increasing doses of public support. On this account we include, the number of support schemes the firm has been enrolled in ("zero" being the reference case). As has been said before, the inclusion of a discrete support dummy always involves the participation issue. In our case the implied endogeneity problem is aggravated by the fact that supported fims participate in various funding schemes, each of them being designed for a particular target group. Given the limited set of available variables there is literally no way to endogenise the funding status in a methodically sound way. If we include the number of support schemes the fim is participating in instead, the type of support is irrelevant and hence the funding status entails no systematic information on the type of fim that benefits from a particular measure. For instance, firms participating in just one support program may appreciate tax allowances, they may have tapped soft financing loans from various national or regional innovation support programs or they may have attracted funds from the European Framework Programmes. As a consequence, the group of supported fims is less selective. Though this approach does not settle the cardinal problem of endogeneity, it becomes less severe. 
- 13 -

Table 3: The drivers of Resourced-based and Behavioural Additionalitiesa)

\begin{tabular}{|c|c|c|c|c|c|c|c|c|}
\hline Type of Additionaliy & Project & Input & Scale & Acceleration & Scope & & & \\
\hline & $\begin{array}{l}\text { More } \\
\text { R\&D\&d }\end{array}$ & $\begin{array}{c}\text { More own } \\
\text { resourc. }\end{array}$ & $\begin{array}{c}\text { Bigger } \\
\text { projects }\end{array}$ & $\begin{array}{c}\text { Longer } \\
\text { Time-frame }\end{array}$ & $\begin{array}{l}\text { More } \\
\text { Coop. }\end{array}$ & $\begin{array}{l}\text { More } \\
\text { Risk }\end{array}$ & $\begin{array}{l}\text { more } \\
\text { basic }\end{array}$ & $\begin{array}{c}\text { more } \\
\text { applied }\end{array}$ \\
\hline $\begin{array}{l}\text { Supported by } \\
\text { one scheme }\end{array}$ & $\begin{array}{l}0.260 \\
(0.000)\end{array}$ & $\begin{array}{l}0.142 \\
(0.011)\end{array}$ & $\begin{array}{l}0.184 \\
(0.001)\end{array}$ & $\begin{array}{l}0.173 \\
(0.002)\end{array}$ & $\begin{array}{l}0.071 \\
(0.207)\end{array}$ & $\begin{array}{l}0.079 \\
(0.139)\end{array}$ & $\begin{array}{l}-0.038 \\
(0.221)\end{array}$ & $\begin{array}{l}0.064 \\
(0.242)\end{array}$ \\
\hline $\begin{array}{c}\text {...two } \\
\text { schemes }\end{array}$ & $\begin{array}{l}0.321 \\
(0.000)\end{array}$ & $\begin{array}{l}0.129 \\
(0.021)\end{array}$ & $\begin{array}{l}0.268 \\
(0.000)\end{array}$ & $\begin{array}{l}0.173 \\
(0.002)\end{array}$ & $\begin{array}{l}0.115 \\
(0.044)\end{array}$ & $\begin{array}{l}0.160 \\
(0.003)\end{array}$ & $\begin{array}{l}-0.050 \\
(0.101)\end{array}$ & $\begin{array}{l}0.086 \\
(0.118)\end{array}$ \\
\hline $\begin{array}{c}\ldots \text { three schemes } \\
\text { and more }\end{array}$ & $\begin{array}{l}0.360 \\
(0.000) \\
\end{array}$ & $\begin{array}{l}0.208 \\
(0.000) \\
\end{array}$ & $\begin{array}{l}0.251 \\
(0.000)\end{array}$ & $\begin{array}{l}0.168 \\
(0.003) \\
\end{array}$ & $\begin{array}{l}0.207 \\
(0.000) \\
\end{array}$ & $\begin{array}{l}0.177 \\
(0.002) \\
\end{array}$ & $\begin{array}{l}-0.046 \\
(0.146) \\
\end{array}$ & $\begin{array}{l}0.079 \\
(0.165) \\
\end{array}$ \\
\hline $\begin{array}{l}\text { High } \\
\text { Cost }\end{array}$ & $\begin{array}{l}0.052 \\
(0.108)\end{array}$ & $\begin{array}{l}0.021 \\
(0.501)\end{array}$ & $\begin{array}{l}0.083 \\
(0.009)\end{array}$ & $\begin{array}{l}0.020 \\
(0.528)\end{array}$ & $\begin{array}{l}0.012 \\
(0.678)\end{array}$ & $\begin{array}{l}0.027 \\
(0.343)\end{array}$ & $\begin{array}{l}-0.007 \\
(0.729)\end{array}$ & $\begin{array}{l}0.010 \\
(0.728)\end{array}$ \\
\hline $\begin{array}{l}\text { Technical } \\
\text { Risk }\end{array}$ & $\begin{array}{l}-0.040 \\
(0.228)\end{array}$ & $\begin{array}{l}0.034 \\
(0.296)\end{array}$ & $\begin{array}{l}0.003 \\
(0.927)\end{array}$ & $\begin{array}{l}0.049 \\
(0.136)\end{array}$ & {$\left[\begin{array}{l}-0.009 \\
(0.766)\end{array}\right.$} & $\begin{array}{l}0.077 \\
(0.012)\end{array}$ & $\begin{array}{l}0.003 \\
(0.876)\end{array}$ & $\begin{array}{l}-0.005 \\
(0.876)\end{array}$ \\
\hline $\begin{array}{l}\text { Commer- } \\
\text { cial risk }\end{array}$ & $\begin{array}{l}-0.021 \\
(0.505)\end{array}$ & $\begin{array}{l}0.030 \\
(0.318)\end{array}$ & $\begin{array}{l}-0.029 \\
(0.360)\end{array}$ & $\begin{array}{l}-0.007 \\
(0.821)\end{array}$ & $\begin{array}{l}0.025 \\
(0.399)\end{array}$ & $\begin{array}{l}0.065 \\
(0.021)\end{array}$ & $\begin{array}{l}0.021 \\
(0.259)\end{array}$ & $\begin{array}{l}-0.033 \\
(0.259)\end{array}$ \\
\hline $\begin{array}{l}\text { Time to } \\
\text { Market }\end{array}$ & $\begin{array}{l}-0.029 \\
(0.376)\end{array}$ & $\begin{array}{l}0.027 \\
(0.396)\end{array}$ & $\begin{array}{l}0.061 \\
(0.061)\end{array}$ & $\begin{array}{l}0.100 \\
(0.002)\end{array}$ & $\begin{array}{l}-0.020 \\
(0.497)\end{array}$ & $\begin{array}{l}-0.027 \\
(0.340)\end{array}$ & $\begin{array}{l}-0.006 \\
(0.739)\end{array}$ & $\begin{array}{l}0.010 \\
(0.740)\end{array}$ \\
\hline $\begin{array}{l}\text { Amorti- } \\
\text { sation }\end{array}$ & $\begin{array}{l}0.024 \\
(0.510)\end{array}$ & $\begin{array}{l}0.000 \\
(0.997)\end{array}$ & $\begin{array}{l}0.034 \\
(0.350)\end{array}$ & $\begin{array}{l}0.021 \\
(0.550)\end{array}$ & $\begin{array}{l}-0.047 \\
(0.145)\end{array}$ & $\begin{array}{l}0.023 \\
(0.477)\end{array}$ & $\begin{array}{l}0.036 \\
(0.100)\end{array}$ & $\begin{array}{l}-0.056 \\
(0.084)\end{array}$ \\
\hline $\begin{array}{l}\text { Property } \\
\text { Rights }\end{array}$ & $\begin{array}{l}-0.059 \\
(0.087)\end{array}$ & $\begin{array}{l}-0.040 \\
(0.229) \\
\end{array}$ & $\begin{array}{l}-0.005 \\
(0.873)\end{array}$ & $\begin{array}{l}-0.053 \\
(0.116)\end{array}$ & $\begin{array}{l}-0.008 \\
(0.794)\end{array}$ & $\begin{array}{l}-0.028 \\
(0.360)\end{array}$ & $\begin{array}{l}-0.020 \\
(0.306)\end{array}$ & $\begin{array}{l}0.033 \\
(0.318)\end{array}$ \\
\hline $\begin{array}{l}\text { Organi- } \\
\text { sation }\end{array}$ & $\begin{array}{l}0.029 \\
(0.628)\end{array}$ & $\begin{array}{l}-0.081 \\
(0.125) \\
\end{array}$ & $\begin{array}{l}0.039 \\
(0.508)\end{array}$ & $\begin{array}{l}0.067 \\
(0.259)\end{array}$ & $\begin{array}{l}0.087 \\
(0.139)\end{array}$ & $\begin{array}{l}0.012 \\
(0.818)\end{array}$ & $\begin{array}{l}0.024 \\
(0.514)\end{array}$ & $\begin{array}{l}-0.036 \\
(0.491)\end{array}$ \\
\hline $\begin{array}{c}\text { Skill } \\
\text { Shortage }\end{array}$ & $\begin{array}{l}0.011 \\
(0.814) \\
\end{array}$ & $\begin{array}{l}-0.053 \\
(0.202) \\
\end{array}$ & $\begin{array}{l}0.063 \\
(0.163)\end{array}$ & $\begin{array}{l}0.089 \\
(0.046) \\
\end{array}$ & $\begin{array}{l}0.044 \\
(0.298) \\
\end{array}$ & $\begin{array}{l}0.039 \\
(0.344) \\
\end{array}$ & $\begin{array}{l}0.033 \\
(0.242)\end{array}$ & $\begin{array}{l}-0.050 \\
(0.213) \\
\end{array}$ \\
\hline $\begin{array}{l}\text { High-tech } \\
\text { Manufac. }\end{array}$ & $\begin{array}{l}-0.026 \\
(0.513)\end{array}$ & $\begin{array}{l}0.041 \\
(0.288)\end{array}$ & $\begin{array}{l}0.042 \\
(0.298)\end{array}$ & $\begin{array}{l}0.041 \\
(0.303)\end{array}$ & $\begin{array}{l}-0.037 \\
(0.313)\end{array}$ & $\begin{array}{l}0.025 \\
(0.496)\end{array}$ & $\begin{array}{l}0.022 \\
(0.353)\end{array}$ & $\begin{array}{l}-0.035 \\
(0.344)\end{array}$ \\
\hline $\begin{array}{l}\text { Tra dition. } \\
\text { Services }\end{array}$ & $\begin{array}{l}-0.032 \\
(0.550)\end{array}$ & $\begin{array}{l}-0.048 \\
(0.348)\end{array}$ & $\begin{array}{l}-0.077 \\
(0.140)\end{array}$ & $\begin{array}{l}-0.058 \\
(0.263)\end{array}$ & $\begin{array}{l}0.058 \\
(0.279)\end{array}$ & $\begin{array}{l}-0.034 \\
(0.461)\end{array}$ & $\begin{array}{l}-0.026 \\
(0.367)\end{array}$ & $\begin{array}{l}0.044 \\
(0.393)\end{array}$ \\
\hline $\begin{array}{l}\text { Knowl.- } \\
\text { Int. Serv. }\end{array}$ & $\begin{array}{l}0.049 \\
(0.288)\end{array}$ & $\begin{array}{l}0.061 \\
(0.177) \\
\end{array}$ & $\begin{array}{l}0.033 \\
(0.474)\end{array}$ & $\begin{array}{l}-0.020 \\
(0.660)\end{array}$ & $\begin{array}{l}0.065 \\
(0.143)\end{array}$ & $\begin{array}{l}0.039 \\
(0.354) \\
\end{array}$ & $\begin{array}{l}-0.010 \\
(0.714)\end{array}$ & $\begin{array}{l}0.016 \\
(0.718) \\
\end{array}$ \\
\hline $\begin{array}{l}>10 \\
\text { employees }\end{array}$ & $\begin{array}{l}0.107 \\
(0.006)\end{array}$ & $\begin{array}{l}0.029 \\
(0.440)\end{array}$ & $\begin{array}{l}0.175 \\
(0.000)\end{array}$ & $\begin{array}{l}0.045 \\
(0.240)\end{array}$ & $\begin{array}{l}-0.027 \\
(0.462)\end{array}$ & $\begin{array}{l}0.083 \\
(0.019)\end{array}$ & $\begin{array}{l}0.041 \\
(0.085)\end{array}$ & $\begin{array}{l}-0.064 \\
(0.078)\end{array}$ \\
\hline $\begin{array}{l}>100 \\
\text { employees }\end{array}$ & $\begin{array}{l}0.186 \\
(0.000)\end{array}$ & $\begin{array}{l}0.007 \\
(0.900)\end{array}$ & $\begin{array}{l}0.217 \\
(0.000)\end{array}$ & $\begin{array}{l}0.097 \\
(0.069)\end{array}$ & $\begin{array}{l}0.050 \\
(0.343)\end{array}$ & $\begin{array}{l}0.134 \\
(0.010)\end{array}$ & $\begin{array}{l}0.072 \\
(0.055)\end{array}$ & $\begin{array}{l}-0.103 \\
(0.029)\end{array}$ \\
\hline $\begin{array}{c}>250 \\
\text { employees }\end{array}$ & $\begin{array}{l}0.097 \\
(0.059) \\
\end{array}$ & $\begin{array}{l}0.019 \\
(0.717) \\
\end{array}$ & $\begin{array}{l}0.226 \\
(0.000)\end{array}$ & $\begin{array}{l}0.207 \\
(0.000) \\
\end{array}$ & \begin{tabular}{|l|l}
0.073 \\
$(0.154)$ \\
\end{tabular} & $\begin{array}{l}0.184 \\
(0.000) \\
\end{array}$ & $\begin{array}{l}0.155 \\
(0.000) \\
\end{array}$ & $\begin{array}{l}-0.197 \\
(0.000) \\
\end{array}$ \\
\hline Start-up & $\begin{array}{l}0.011 \\
(0.787) \\
\end{array}$ & $\begin{array}{l}0.022 \\
(0.579) \\
\end{array}$ & $\begin{array}{l}0.116 \\
(0.004)\end{array}$ & $\begin{array}{l}0.080 \\
(0.048) \\
\end{array}$ & $\begin{array}{l}0.039 \\
(0.312) \\
\end{array}$ & $\begin{array}{l}0.022 \\
(0.548) \\
\end{array}$ & $\begin{array}{l}-0.006 \\
(0.782)\end{array}$ & $\begin{array}{l}0.010 \\
(0.785) \\
\end{array}$ \\
\hline $\begin{array}{l}N \\
\text { Observed } \operatorname{Pr}(y=1) \\
\text { Predicted } \operatorname{Pr}(y=1)\end{array}$ & $\begin{array}{l}961 \\
0.513 \\
0.521 \\
\end{array}$ & $\begin{array}{l}944 \\
0.408 \\
0.410 \\
\end{array}$ & $\begin{array}{l}953 \\
0.477 \\
0.493 \\
\end{array}$ & $\begin{array}{l}948 \\
0.453 \\
0.469 \\
\end{array}$ & $\begin{array}{l}937 \\
0.333 \\
0.318 \\
\end{array}$ & $\begin{array}{l}945 \\
0.330 \\
0.333 \\
\end{array}$ & $\begin{array}{l}935 \\
0.164 \\
0.153 \\
\end{array}$ & $\begin{array}{l}935 \\
0.390 \\
0.387 \\
\end{array}$ \\
\hline
\end{tabular}

Source: FFF-survey; a) marginal effects ( $p$-values in parentheses)

Furthermore, a list of possible bamiers to innovation enters the regression equation. The latter are coded as dummies where the reference group is given by the set of fims that rates the 
suggested obstacle as irrelevant. Last, we proceed as Wong and He (2003) and include basic background characteristics such as sectoral affiliation and size of the firm. As an additional control variable we coded a "start-up dummy" which is equal to one if the fim had been founded within the last five years prior to the survey.

Table 3 lists the marginal effects and associated marginal probabilities in the event of a positive change. The first important thing to note is that the predicted probabilities resulting from this specification (last line) deviate very little from their unconditional (observed) counterparts - i.e. the model is well specified. As one would hope, the realisation of various dimensions of additiona lity ma inly depends on the number of different support schemes fims have taken advantage of. The responses to increased doses of public support reveal an interesting pattem summarised in Table 4.

Table 4: Kick-off and cumulative effects of public fundinga)

\begin{tabular}{|c|c|c|c|c|}
\hline & & \multicolumn{3}{|c|}{ Cumulative effects? } \\
\hline & & Yes & & No \\
\hline 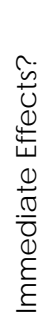 & 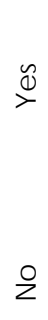 & $\left.\begin{array}{l}\text { Project Additionality } \\
\text { Input Additionality } \\
\text { Scale Additionality }\end{array}\right\}$ & $\left\{\begin{array}{c}\text { Pr ocess }-\& \text { Result } \\
\text { based } \\
\text { concepts }\end{array}\right.$ & $\left.\begin{array}{l}\text { Acceleration } \\
\text { Additionality }\end{array}\right\} \begin{array}{c}\text { Process } \\
\text { based } \\
\text { concept }\end{array}$ \\
\hline
\end{tabular}

a) Summa rises results from the first three lines in Table 3

Firms tend to immediately increase their resources devoted to innovation projects and their additional resource input increases with the number of schemes in which they participate. Acceleration additionalities also immediately come into effect, but fims do not further extend the time horizon of their research projects when participating in more schemes. Finally, additionalities in scope a re clearly once aga in accumula tive, but they only come into effect once a certain threshold level of intervention has been reached. The willingness to engage in riskier projects or to create new collaborations only comes into effect after repeated treatment. ${ }^{10}$ The latter accords well with the mixed evidence on the role of public policy in creating research collaborations results (see Wong and He (2003) and the previously cited studies). Both the kick-off and cumulative effects of funding can also be observed with respect to the size of the firm. Start-ups are typically small fims. In our sample, half of them have fewer than 10 employees on their payrolls (see Table 7 in the Appendix). These fims are more likely to engage in larger and longer term projects. Their probability of realizing scale additionalities is $\mathbf{1 1 . 6}$ percentage points higher than that of matured fims, and their

\footnotetext{
10 The same holds true with respect to changes in the research focus, although, admittedly, the coefficient of "participation in two programs" is of borderline signific ance at best.
} 
willingness to extend the time-horizon of their projects increases by 8 percentage points. At the same time, we find that scale and acceleration additionalities increase with firm size, as do project additionalities (1 $1^{\text {st }}$ column) and scope additionalities in the form of greater risktaking and willingness to undertake basic research.

The finding that in Austria classical input additionality ( $2^{\text {nd }}$ column) does not depend on the size of the firm is unusual. Schibany et al. (2004) showed that Austrian fims with fewer than 10 employees and firms with more than 250 employees exhibit the highest leverage from public funding. The different findings can most likely be attributed to the measure of inputadditiona lity: Our survey-based analysis makes use of a categorical concept, i.e. the firm reports spending "more or less or the same amount of its own resources" on its STl activities.

Based on our admittedly broad classification, we find that fims experience (or do not experience) additiona lities irrespective of their sectoral affiliation. We investigated this issue in more detail in a subsequent exercise where the original sub-branches entered the regression equations instead of the aggregate industries. The marginal effects associated with these branch dummies are displayed, where statistic ally signific ant, in the last column of Table 5 in the Appendix. The results show that quite a few industries from both the low-tech and hightech manufacturing sectors show signific antly higher probabilities of running more long-term projects than those in the reference sector (manufacture of metal products \& parts). Any other behavioural change, such as engagement in more cooperative or risky projects or an investment in long-term projects, rema ins unaffected by the sectoral affiliation of the firm.

Finally, we tum to the question of how the Austrian support system responds to the perceived ba miers to innovation. Companies undertaking $R \& D \& I$ apparently struggle with a great deal of problems. Figure 3 in the Appendix ranks select problems in descending order of importance. The largest obstacles to innovation are the high costs thereof. More than 60 percent of the fims from the estimation sample complained about the pricey outlays that would restrict respective engagements. Cost-constrained fims benefit from the Austrian funding scheme insofar as they run projects on a larger scale than they otherwise would. Their probability of engaging in larger projects increases by 8.3 percentage points (compared to the reference group of unconstra ined fims). Furthermore, the coefficient on "high cost" is just about significant in the first regression, i.e. cost-constrained firms conduct more R\&D\&Iprojects than would be the case if there were no innovation policies in place. However, more numerous and larger projects do not induce the firm to devote more of its own resources to the target activity. The relevant marginal effect in the classical input a dditiona lity regression is far from statistically significant. Hence, increased investments are supported completely by the public sector. If the success of the Austrian innovation support system were to be judged on the basis of the classical resource-based concepts of additionality (i.e. project and input additionality), we would find that it is not effective in tackling problems other than the notorious complaint about the excessive costs of innovation. In particular, the acquisition problem of R\&D is not effec tively handled. Fims expressing a concem about the inadequate protection of intellectual property would reduce their R\&D-activities even if they participated in a public R\&D-promotion scheme. For this group, the probability of extending respective activities decrea ses by 8.7 percenta ge points and the decrease is signific ant. 
With the exception of the unresolved issue of intellectual property protection, Austrian economic policies are effective in mitigating the fims' bamiers to innovation. However, alleviations do not express themselves in tems of greater resource inputs, but rather in terms of behavioural changes. Commercial risks rank second in the list of bariers to innovation every other fim addresses this obstacle and a nother 35 percent of the sample fims refer to the high technological risk associated with innovation activities. As one would hope, riskconstrained fims declare that the availability of support schemes has led them to engage in more risky R\&D-projects. Long amortisation periods are also successfully dealt with to the extent that fims addressing this kind of problem tend to undertake more basic research and companies struggling with a long time to market are more willing to undertake long-term projects.

\section{Conclusions}

This paper deals with the effects of polic y intervention in the fields of science, technology and innovation. Both traditional resource-based additionality concepts and the more recent concept of behavioural additionality are applied to a 2003 survey of Austrian fims, most of which received some form of public assistance.

The first important result is that the innovation support system in general is not only benefic ial to firms that actually receive support, but also to potentially supported fims - though naturally to a lesser extent. Several conclusions may be drawn from this finding. First, since additionalities already accrue during the application process, the management of funding processes deserves greater attention. The incentive effects a rising from "the right" funding criteria may have no less of an impact than the sheer a mount of dedic ated moneys. Second, the direction of causa lity between the causes and effects of funding is not as straightforward as the mainstream literature suggests. This challenges current econometric approaches to additionality and also raises some questions as to the usefulness of evaluating the performance of individual programmes. Direct questions on the merits of policy intervention are admittedly a crude way to investigate the performance of the national innovation system, and yet they are more instrumental in tracing the spillovers and synergies that arise from it.

The second major finding is that the effects of policy intervention are cumulative in a dual sense. On the one hand, our results confim the well-known notion that the largest fims are the most likely to realize various forms of additionality. Depending on the methodical approach used, we observed either a linear or U-shaped relationship between policy intervention and additionality. In either case, large fims appeared to make the best use of funds. On the other hand, substantial changes in the way a company undertakes R\&D\&Irelated a ctivities appear to only result from repeated trea tment, i.e. different kind s of multiple policy interventions are necessary in order to trigger scope additionalities in the form of more cooperation or a greater willingness to engage in risky basic research. This strongly supports what we previously argued: that, due to the cumulative nature of behavioural (and resultsbased) additiona lity concepts, the results of intervention only become visible years after the 


$$
\text { - } 17 \text { - }
$$

money has been spent, and that it is diffic ult to attribute changes in "the way a company undertakes its STl activities" to discrete measures or programmes. When one acknowledges that the success of policy intervention does not solely depend on individual fund ing schemes, it becomes clear that future work should focus more on the evaluation of portfolios of programmes and their interactions.

Similarly, our results suggest that the effectiveness of policy interventions cannot be adequately captured by relying on a single impact measure. Depending on the perceived ba miers to innovation, different dimensions of (behavioural) a dditionality should be applied in order to draw conclusions about the effectiveness of a scheme or a system in general. Furthemore, it seems vital to link the resource-based and process-based concepts of additionality to eventual outcomes. Increased innovation inputs do not necessarily lead to more innovation output, and in a similar way, behavioural changes constitute only intermediate results. This concem partic ularly applies to scope additionalities. It is, of course, essentially desirable for fims to be encouraged to think 'outside the box' and beyond shortsighted business needs. In the end, however, behavioural changes should be economically justifiable; if not at the level of the firm, then certainly at the aggregate level. 


\section{Appendix}

Table 5: Sectoral classification

\begin{tabular}{|c|c|c|c|}
\hline Industry & abs. freq. & in $\%$ & Additionality (marginal effect, if signific ant)a) \\
\hline Low-tech manufacturing industries & 310 & 23.9 & \\
\hline Manufacture of food, beverages $\&$ tobacco & 42 & 3.2 & Longer time-fra me $(0.157)$ \\
\hline Manufacture of textile \& leather & 16 & 1.2 & Longer time-frame $(0.278)$ \\
\hline Manufacture of wood \& wood products & 35 & 2.7 & Longer time-frame $(0.257)$ \\
\hline Manufacture of paper \& paper products & 15 & 1.2 & \\
\hline Printing, publishing $\&$ allied industries & 8 & 0.6 & \\
\hline Manufacture of rubber \& plastics & 36 & 2.8 & \\
\hline Manufacture of non-metallic mineral products & 22 & 1.7 & Longer time-frame (0.199) \\
\hline Basic metal \& alloys industries & 50 & 3.9 & Longer time-frame $(0.16)$ \\
\hline Manufacture of metal products $\&$ parts & 68 & 5.2 & \\
\hline Manufacture of fumiture, jewelry $\&$ musical instr. & 18 & 1.4 & \\
\hline R\&D-intensive manufacturing industries & 393 & 30.3 & \\
\hline Manufacture of basic chemicals \& chem. Prod. & 57 & 4.4 & Longer time-frame (0.214); Bigger projects $(0.167)$ \\
\hline Manufacture of machinery \& equipment & 151 & 11.7 & Longer time-frame $(0.147)$ \\
\hline Manufacture of office computing $\&$ & & & \\
\hline accounting machinery and parts & 9 & 0.7 & More risk $(0.350)$ \\
\hline Manufacture of apparatus forgeneration & & & \\
\hline$\&$ transmission of electricity & 24 & 1.9 & \\
\hline Manufacture of apparatus for radio broadcasting, & & 0.0 & \\
\hline TV transmission \& communication engineering & 16 & 1.2 & Longer time-frame (0.248) \\
\hline Manufacture of medical \& surgical instruments, & & & \\
\hline and of scientific and measuring equipment & 100 & 7.7 & Longer time-frame $(0.157)$ \\
\hline Manufacture of transport equipment $\&$ parts & 36 & 2.8 & Longer time-frame $(0.265)$ \\
\hline Non knowledge-intensive (traditional) services & 145 & 11.2 & \\
\hline Recycling, power- and water-supply & 23 & 1.8 & \\
\hline Building trade and civil engineering & 68 & 5.2 & \\
\hline Wholesale trade, retail trade, & & & \\
\hline trade $\&$ repair of motor vehicles & 23 & 1.8 & \\
\hline Tourism \& hotel busineß & 3 & 0.2 & \\
\hline Transport \& traffic & 10 & 0.8 & \\
\hline Sewage \& rubbish disposal and other disposal & 18 & 1.4 & \\
\hline Knowledge-intensive services & 365 & 28.2 & \\
\hline News transmission, broadcasting, TV & 6 & 0.5 & \\
\hline Credit $\&$ insurance agencies and allied services & 1 & 0.1 & \\
\hline Software, data-processing and database & 160 & 12.3 & Longer time-frame $(0.155)$ \\
\hline Research \& development & 106 & 8.2 & \\
\hline Enterprise-related services & 63 & 4.9 & \\
\hline Teaching, instruction $\&$ education & 10 & 0.8 & Time-fra me (0.392); Riskier (0.688); more applied (0.616) \\
\hline Health, veterinary medicine and social services & 10 & 0.8 & \\
\hline Cultural industries, sports $\&$ enterta inment & 9 & 0.7 & \\
\hline Other branches/miscellaneous & 72 & 5.6 & \\
\hline Missing industry affiliation & 11 & 0.8 & \\
\hline TOTAL & 1296 & 100 & \\
\hline
\end{tabular}

Source: FFF-survey; a)Reference sector: Manufacture of metal products \& parts 
- 19 -

Table 6: Joint distribution of sector affiliation and firm-size

\begin{tabular}{|c|c|c|c|c|c|c|}
\hline \multirow[b]{2}{*}{ Sectoral affiliation } & \multicolumn{5}{|c|}{ firm size as measured by the number of employees } & \multirow[b]{2}{*}{ Tota } \\
\hline & $<10$ & 10-99 & $100-249$ & 250 and more & missing & \\
\hline Low-tech industries & 51 & 110 & 65 & 77 & 7 & 310 \\
\hline$R \& D$-intensive industries & 110 & 149 & 55 & 71 & 8 & 393 \\
\hline Tra ditional services & 63 & 48 & 10 & 18 & 6 & 145 \\
\hline Knowledge-intensive services & 187 & 137 & 12 & 11 & 18 & 365 \\
\hline others/misc ella neous & 31 & 28 & 6 & 5 & 2 & 72 \\
\hline Missing & 4 & 2 & 1 & 1 & 3 & 11 \\
\hline Total & 446 & 474 & 149 & 183 & 44 & 1,296 \\
\hline
\end{tabular}

Source: FFF-survey

Table 7: Distribution of firm-size for newly founded and matured fims

\begin{tabular}{|c|c|c|c|c|c|}
\hline \multirow[b]{2}{*}{ Type of firm } & \multicolumn{4}{|c|}{ firm size as measured by the number of employees } & \multirow[b]{2}{*}{ Total } \\
\hline & $<10$ & $10-99$ & $100-249$ & 250 and more & \\
\hline Mature fims & 25.06 & 41.53 & 15.56 & 17.85 & 100 \\
\hline Founded within the last 5 years & 50.24 & 34.15 & 5.37 & 10.24 & 100 \\
\hline Total & 29.84 & 40.13 & 13.62 & 16.4 & 100 \\
\hline
\end{tabular}

Source: FFF-survey

Figure 3: Barriers to innovation

High cost of innovation

\section{Commercial risk}

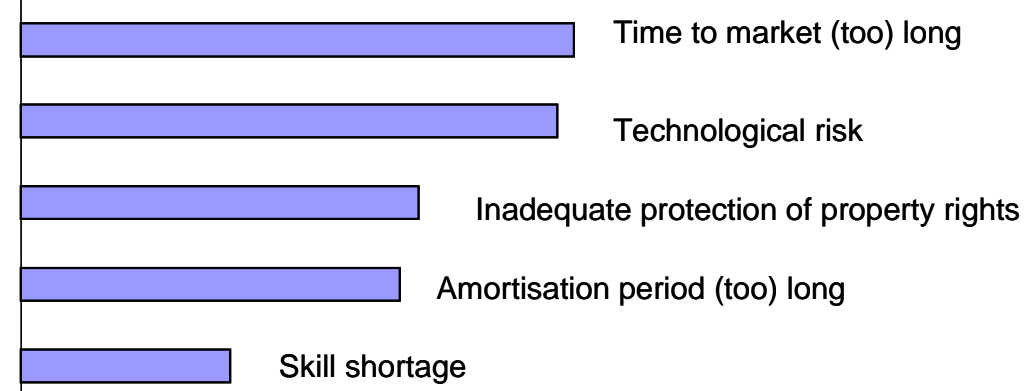

Cooperation with scientific partners

Organisation of $R \& D \& I$ activities within the firm

$\begin{array}{llllllllllllllllllll}5 & 10 & 15 & 20 & 25 & 30 & 35 & 40 & 45 & 50 & 55 & 60 & 65 & 70 & 75 & 80 & 85 & 90 & 95 & \text { percent }\end{array}$ Source: FFF-survey 
Table 8: Actual vs. hypothetical Project Additionalities: Detailed Analysis

\begin{tabular}{|c|c|c|c|c|c|}
\hline & \multicolumn{2}{|c|}{ Ana lysis by fim-size } & \multicolumn{2}{|c|}{ Analysis by sectoral a ffilia tion } & \\
\hline & Hypothetical & Actual & Hypothetical & Actual & \\
\hline $\begin{array}{l}\text { Fim-size as mea sured } \\
\text { by number of empl. }\end{array}$ & \multicolumn{4}{|c|}{ Project is carried out without change (no project additionality) } & Sectoral affiliation \\
\hline less than 10 & 8.4 & 14.08 & 18.52 & 34.02 & low-tech manuf. \\
\hline 10 and more & 13.4 & 19.15 & 13.02 & 23.61 & high-tech manuf. \\
\hline 100 and more & 18.82 & 42.31 & 15.12 & 18.75 & traditional services \\
\hline 250 und more & \multicolumn{4}{|c|}{$\begin{array}{l}\text { Revised version of the project is carried out } \\
\text { (partial project additionality) }\end{array}$} & knowl.-intens. Serv. \\
\hline less than 10 & 50 & 47.18 & 58.2 & 46.39 & low-tech manuf. \\
\hline 10 and more & 60.14 & 43.97 & 62.33 & 47.92 & high-tech manuf. \\
\hline 100 and more & 57.65 & 44.23 & 47.67 & 41.67 & tra ditional services \\
\hline 250 und more & Proje & $\begin{array}{l}51.69 \\
\text { is cance }\end{array}$ & 57.37 & 47.73 & knowl.-intens. Serv. \\
\hline less than 10 & 41.6 & 38.73 & 23.28 & 19.59 & low-tech manuf. \\
\hline 10 and more & 26.46 & 36.88 & 24.65 & 28.47 & high-tech manuf. \\
\hline 100 and more & 23.53 & 13.46 & 37.21 & 39.58 & tra ditional services \\
\hline 250 und more & 12.94 & 21.35 & 34.74 & 40.15 & knowl.-intens. Serv. \\
\hline
\end{tabular}

Source: FFF; Details evidence from Table 1 


\section{References}

Arrow, Kenneth J . (1962), Economic welfare and the allocation of resources for invention, in Richard Nelson (ed.), The rate and direction of inventive activity: Economic and social factors, pp. 609-625, Princeton University Press, Princeton, N.J .

Aslesen, Heidi W., Marianne Broch, Per M. Koch and Nils H. Solum (2001), User oniented R\&D in the Research Council of Norway, Technopolis RCN evaluation, Oslo.

Branstetter, Lee G. and Mariko Sakakibara (2002), When do research consortia work well and why? Evidence from Japanese panel data, American Economic Review, Vol. 92,1, pp. 143-159.

Buisseret, Timothy J., Hugh M. Cameron and Luke Georghiou (1995), What difference does it make? Additionality in the public support of R\&D in large fims, Intemational J oumal of Technology Management, Vol. 10, pp. 587-600.

Czamitzki, Dirk, Bemd Ebersberger and Andreas Fier (2004), The relationship between R\&D collaboration, subsidies and patenting activity: empirical evidence from Finland and Gemany, 正W Disc ussion Paper No. 04-37.

Davenport, Sally, Charlotte Grimes and J ohn Davies (1998), Research collaboration and behavioural additionality: a New Zealand case study, Technology Analysis \& Strategic Management, March 1998, pp. 55-67.

David, Paul A., Bronwyn H. Hall and Andrew A. Toole (2000), Is public R\&D a complement or substitute for private $R \& D$ ? A review of the econometric evidence, Research Policy, Vol. 29, pp. 497-529.

Dodgson, Mark and Roy Rothwell (eds.) (1994), The handbook of industrial innovation, Edward Elgar Publishing, Cheltenham.

Fagerberg, J an, David C. Mowery and Richard R. Nelson (2004) The Oxford handbook of innovation, Oxford University Press, Oxford.

Falk, Martin (2004), Productivity effects of R\&D subsidies: evidence from fim-level panel data, Tip Working Paper.

Fransman, Martin (1990), The market and beyond: cooperation and competition in information technology, Cambridge University Press, Cambridge.

Freeman, Chris (1994), The economic s of technical change, Cambridge Journal of Economics, Vol. 18, pp. 463-514.

Garcia, Abraham and Pierre Mohnen (2004), Impact of govemment funding on R\&D and innovation, Background Report to the European Competitiveness Report 2004, chapter 2.4.1.

García-Quevedo, J ose (2004), Do public subsidies complement business R\&D? A meta-analysis of the econometric evidence, Kyklos, Vol. 57, 1, pp. 87-102.

Georghiou, Luke, (1997), Issues in the evaluation of innovation and technology policy, in: Policy evaluation in innovation and technology: towards best practice, chapter $3, O E C D$, Paris.

Georghiou, Luke and David Roessner (2000), Evaluating technology programs: tools and methods, Research Policy, Vol. 29, pp. 657- 678.

Georghiou, Luke, (2002), Impact and additionality of innova tion polic y, IWT-Studies No. 40, pp- 57-65.

Georghiou, Luke, Keith Smith, Otto Toivanen, Pekka Ylä-Anttila.,"Evaluation of the Finnish innovation support system", Ministry of Tra de and Industry, 2003, Finland.

Gottschalk, Sandra and Norbert Janz (2003), Bestimmungsfaktoren der Innovationstätigkeit, in: Norbert Janz and Georg Licht (eds.), Innovationsforschung heute, 正W Wirtschaftsanalysen, Vol. 63, Ba den-Baden, 2003, pp.17-39.

Hyvärinen, Jari (2005), Measuning behavioural additionality effects of public R\&D funding: A Study of Finland, Tekes Working Paper.

Klette, Tor J., Jarle Møen and Zvi Griliches (2000), Do subsidies to commercial R\&D reduce market failure? Mic roeconometric evaluation studies, Research Policy, Vol. 29, pp. 471-495.

Luukkonen, Terttu (2000), Additionality of EU framework programmes, Research Policy, Vol. 29, pp. 711-724.

Metcalfe, Stan (1995), The economic foundations of technology policy: equilibrium and evolutionary perspectives, in Paul Stoneman (ed.), Handbook of the economics of innovation and technological change, Blackwell, Oxford. 
Nelson, Ric hard R. (1959), The simple economics of basic scientific research, J oumal of Political Economy, 67, pp. 297306.

OECD (2005), The behavioural additionality of R\&D grants: introduction and preliminary synthesis, OECD Working Party on Innovation and Technology Policy.

Papaconstantiou, George and Wolfgang Polt (1997), Policy evaluation in innovation and technology: an overview, in: Polic y evaluation in innovation and technology: towards best practice, chapter 1, OECD, Paris.

Pegler, Bob (2005), Behavioural additionality in Australian business R\&D grant programs, Paper presented at the OECD Workshop on Behavioural Add itiona lity in Vienna, J anuary 2005.

Rigby, John (2003), ASIF: Evaluating socio-economic impact, Plattform Forschungs-und Technologieevaluienung No. 17 (March 2003), pp. 13-17.

Schibany, Andreas, Gerhard Streicher, Nikolaus Gretzmacher, Martin Falk, Rahel Falk, Norbert Knoll, Gerhard Schwarz, Martin Wörter (2004), Evaluation FFF - Impact analysis, InTeReg Research Report Series No. 22-2004. Download: http://www.joanneum.ac.at/cms_img/img2082.pdf

Sakakibara, Mariko (1997), Evaluating govemment-sponsored R\&D consortia in Japan: who benefits and how, Research Policy, Vol. 26, pp. 447-473.

Shipp, Stephanie, Lorel Wisniewski, Andrew Wang, and Steve Campbel (2005), Measuring behavioral additionality in ATP joint venture projects: Findings from the U.S. Advanced Technology Program, Paper presented at the OECD Workshop on Behavioural Ad ditiona lity in Vienna, J a nuary 2005.

Stoneman, Paul and John Vickers (1988), The assessment: the economics of technology policy", Oxford Review of Economic Policy, Vol. 4, pp. 1-16.

Streicher, Gerhard, Andreas Schibany and Nikola us Gretzmacher (2004), Input a dditionality effects of R\&D subsidies: empiric al evidence from fim-level data, TIP Working Paper, Mach 2004.

Sundbo, J on (1998), The Theory of Innovation: entrepreneurs, technology and strategy, Edward Elgar Publishing, Cheltenham.

Tether, Bruce (2003), The sources and aims of innovation in services: variety between and within sectors, Economics of Innovation and New Technology, Vol. 12, 6, pp. 481-505.

Wong, Poh-Kam and Z-Lin He (2003), the moderating effect of a fim's intemal climate for innovation on the impact of public R\&D support programmes, Intemational Joumal of Entrepreneurship and Innovation Management, Vol. 3, pp. 525-545. 
Medieninhaber (Verleger), Hersteller: Österreichisches Institut für Wirtschaftsforschung • Wien 3, Arsenal, Objekt $20 \bullet$ A-1103 Wien, Postfach 91 • Tel. (43 1) $7982601-0$ • Fax (43 1) 7989386 • http://www.wifo.ac.at/ • Verlags- und Herstellungsort: Wien

Die Working Papers geben nicht notwendigerweise die Meinung des WIFO wieder

Verkaufspreis: EUR 8,00 • Download kostenlos:

http://publikationen.wifo.ac.at/pls/wifosite/wifosite.wifo_search.get_abstract_type?.p_language=1 \&.pubid=25914 